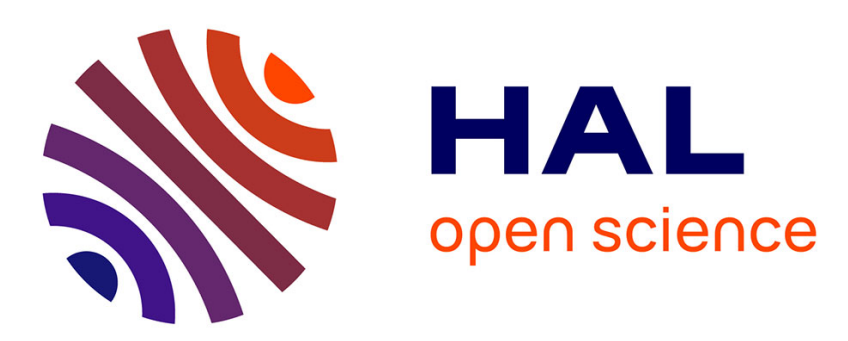

\title{
Non-destructive assessment of human ribs mechanical properties using quantitative ultrasound
}

\author{
David Mitton, Jean-Gabriel Minonzio, Maryline Talmant, Rafaa Ellouz, \\ Frédéric Rongieras, Pascal Laugier, Karine Bruyere-Garnier
}

\section{To cite this version:}

David Mitton, Jean-Gabriel Minonzio, Maryline Talmant, Rafaa Ellouz, Frédéric Rongieras, et al.. Non-destructive assessment of human ribs mechanical properties using quantitative ultrasound. Journal of Biomechanics, 2014, 47 (6), pp.1548-1553. 10.1016/j.jbiomech.2014.01.052 . hal-01417512

\author{
HAL Id: hal-01417512 \\ https://hal.science/hal-01417512
}

Submitted on 15 Dec 2016

HAL is a multi-disciplinary open access archive for the deposit and dissemination of scientific research documents, whether they are published or not. The documents may come from teaching and research institutions in France or abroad, or from public or private research centers.
L'archive ouverte pluridisciplinaire HAL, est destinée au dépôt et à la diffusion de documents scientifiques de niveau recherche, publiés ou non, émanant des établissements d'enseignement et de recherche français ou étrangers, des laboratoires publics ou privés. 


\section{Non-destructive assessment of human ribs mechanical properties using quantitative ultrasound}

David Mitton $^{1}$, Jean-Gabriel Minonzio ${ }^{2,3}$, Maryline Talmant ${ }^{2,3}$, Rafaa Ellouz ${ }^{4}$, Frédéric Rongieras ${ }^{1,5}$, Pascal Laugier $^{2,3}$ and Karine Bruyère-Garnier ${ }^{1}$

Université de Lyon, F-69622, Lyon ; IFSTTAR, LBMC, UMR_T9406; Université Lyon 1, France. ${ }^{2}$ UPMC Univ Paris 6, UMR CNRS7623, Laboratoire d’Imagerie Paramétrique, F-75006, Paris, France ${ }^{3}$ CNRS UMR7623, LIP, F-75006, Paris, France ${ }^{4}$ Université de Lyon, INSERM Unit 1033, F-69372, Lyon, France

${ }^{5}$ Service de chirurgie orthopédique et traumatologique - Hôpital d'instruction des armées Desgenettes - 69003 Lyon, France

\section{Corresponding author:}

David Mitton

Site Ifsttar Lyon-Bron

25 Avenue François Mitterrand

69675 BRON FRANCE

Phone: +33 4721423 61,

Fax: +33472376837

E-mail address: david.mitton@ifsttar.fr

Keywords: Modulus of elasticity, Maximal strength, Cortical bone, Quantitative ultrasound, Ultrasound velocity

Word count: 2144 
Abstract:

Advanced finite element models of the thorax have been developed to study, for example, the effects of car crashes. While there is a need for material properties to parameterize such models, specific properties are largely missing. Non-destructive techniques applicable in vivo would, therefore, be of interest to support further development of thorax models. The only non-destructive technique available today to derive rib bone properties would be based on quantitative computed tomography that measures bone mineral density. However, this approach is limited by the radiation dose. Bidirectional ultrasound axial transmission was developed on long bones ex vivo and used to assess in vivo health status of the radius. However, it is currently unknown if the ribs are good candidates for such a measurement. Therefore, the goal of this study is to evaluate the relationship between ex vivo ultrasonic measurements (axial transmission) and the mechanical properties of human ribs to determine if the mechanical properties of the ribs can be quantified non-destructively. The results show statistically significant relationships between the ultrasonic measurements and mechanical properties of the ribs. These results are promising with respect to a non-destructive and non-ionizing assessment of rib mechanical properties.

This ex vivo study is a first step toward in vivo studies to derive subject-specific rib properties. 


\section{Introduction}

Thoracic injuries are frequently observed in automotive collisions and have been reported to be a major cause of automotive related fatalities (van Don et al. 2003; Kent et al. 2005; Brumbelow et al. 2009). The thorax accounts for approximately 30\% of injuries to belted drivers over age 34 who are fatally injured in frontal collisions (Kent et al. 2005). To improve users' safety, enhanced knowledge of the ribcage biomechanics is needed (Stitzel et al. 2003; Kemper et al. 2005; Vezin et al. 2009). Based on biomechanical knowledge, numerical models have mainly focused on standard individuals (e.g. $50^{\text {th }}$ percentile male) (Ruan et al. 2003; Song et al. 2009). However, there is a need to improve protection for the entire population of transport users. Thus, specific thorax models have been developed for children (Mizuno et al. 2005; Jiang et al. 2012), the small female (Kimpara et al. 2005), and for adults taking into account the aging effect (Kent et al. 2005; El-Jawahri et al. 2010; Forman et al. 2012). The global geometry of the ribcage can be obtained from medical imaging, and in particular using biplanar Xrays (Dansereau et al. 1988; Benameur et al. 2005; Mitton et al. 2008; Jolivet et al. 2010), to build these specific models. Detailed geometry (e.g. cortical thickness) can be obtained from high-resolution computed tomography. In addition to these geometrical features, the mechanical properties of the bone must be considered to build specific models, as Kemper et al. concluded (Kemper et al. 2007).

Variations of the trabecular bone properties produce a negligible influence on rib response (Li et al. 2010). Thus, our study focuses on the cortical bone. The age effect on cortical bone mechanical properties has been assessed at the femoral, humeral, and tibial locations. The failure properties (strength, strain, energy) of these cortical bones were found to decrease with age (Lindahl et al. 1967; McCalden et al. 1993; Zioupos et al. 1998), whereas no variation (Lindahl et al. 1967; McCalden et al. 1993) or decrease with age (Zioupos et al. 1998) was reported for the modulus of elasticity. For the ribs, maximal strength was also found to decrease with age (Stein et al. 1976). However, studies which have quantified other material properties of human ribs were either performed on groups of subjects too small (3 to 6 subjects) to draw reliable conclusions regarding the effect of age (Granik et al. 1973; Kemper et al. 2005; Kemper et al. 2007) or the age effect was not assessed (Yoganandan et al. 1998; Subit et al. 2013). In addition, the effect of age has not been well documented for children due to the limited 
availability of paediatric tissue (Agnew et al. 2013; Crandall et al. 2013). Thus, a non-invasive technique applicable in vivo is of interest for the assessment of age effect on the mechanical properties of the rib cortical bone during both growth and aging.

How can the apparent mechanical properties of the ribs be measured non-invasively? Today, quantitative computed tomography is the only clinical modality that could provide a non-invasive estimation of rib mechanical properties based on rib density measurements. This approach relies on the hypothesis that the relationship between bone mineral density (assessed using quantitative computed tomography) and modulus of elasticity, which has been determined for vertebral cancellous bone (Kopperdahl et al. 2002) and femoral cortical bone (Duchemin et al. 2008)) can be determined for the ribs (Zhu et al. 2013). One drawback of this approach is the radiation dose of this imaging modality. To overcome this limit, ultrasound techniques offer an interesting alternative. An ultrasound method (ex vivo in a water tank) has been applied on rib specimens collected during surgery (Berteau et al. 2012).. In the current paper, bidirectional axial transmission was used as it allows bone examination through the skin (Talmant et al. 2009; Kilappa et al. 2011). We assume that this technique, initially developed for peripheral long cortical bones (radius, tibia, phalanges) (Bossy et al. 2004), can be extended to the ribs. The goal of this study is to assess the relationship between ex vivo ultrasonic measurements (axial transmission) and the mechanical properties of human ribs obtained from three-point bending experiments.

\section{Materials and methods}

\subsection{Specimens}

Seventeen human rib specimens (6 and 8 levels), from 9 subjects (67 to 80 years old) were provided by the Departement Universitaire d'Anatomie Rockefeller (Lyon, France) through the French program on voluntary corpse donation to science. Rib segments (120 mm long) were cut from the midsection of each rib (Figure 1) to perform three complementary measurements. Specimens were kept frozen $\left(-20^{\circ} \mathrm{C}\right)$ until the experiments. They were thawed at $4^{\circ} \mathrm{C}$ for $12 \mathrm{~h}$ and at $20^{\circ} \mathrm{C}$ for 2 hours before the experiments.

\subsection{Experiments}

First, all segments were scanned using a High Resolution peripheral Quantitative Computed Tomography (HRpQCT) device (XtremeCT, Scanco Medical AG, Brüttisellen, Switzerland) that provides parallel slices with an 
isotropic voxel size of $82 \mu \mathrm{m}$ (Figure 2). The orientation of the rib in the CT scanner was maintained in a foam in a similar position to the one of the 3-point bending experiment. Grey level images were segmented semiautomatically using a Gaussian filter and a threshold-based algorithm incorporated within the manufacturer's analysis software ( $\mu \mathrm{CT}$ Evaluation, Scanco Medical AG, Brüttisellen, Switzerland). The separation of the cortical and trabecular bone compartment was based on a double contouring method of the periosteal and endosteal margins (Burghardt et al. 2010).

The Cortical thickness (Ct.Th) and cross-sectional area moment of inertia needed for the calculation of mechanical properties were computed within the scanner manufacturer's Image Processing Language (IPL V5.16, Scanco Medical AG, Brüttisellen, Switzerland). The Ct.Th was calculated using a direct method (Hildebrand et al. 1999).

Then, ultrasound measurements were performed along the bone surface, using the bidirectional axial transmission extensively described in Bossy et al. (Bossy et al. 2004). The ultrasound parameter is the velocity of the first arriving signal (VFAS). Measurements were performed on the central area of the samples, with the probe positioned on the external side of the rib, using a standard ultrasound gel. The average value of triplicate VFAS measurements performed on each specimen with intermediate repositioning was kept for the final analysis.

Finally, three-point bending experiments (Figure 3) were performed until failure. A servo-hydraulic testing machine (INSTRON 8802, High Wycombe, England) with a sampling rate of $1000 \mathrm{~Hz}$ and no filter was used. Tests were performed at room temperature. Load and displacement were recorded using a $1 \mathrm{kN}$ load cell (accuracy $0.5 \%$ ) and the testing machine displacement transducer (accuracy 1\%), respectively. The loading speed was $0.5 \mathrm{~m} . \mathrm{s}^{-1}$ (Cormier et al. 2005). The modulus of elasticity and the maximal bending strength were computed in two ways:

1/ analytically assuming that the rib is a beam with a constant cross-section, using the following equations:

$$
\begin{aligned}
& E_{a}=K{\frac{L^{3}}{48 I}}^{3} \\
& \sigma_{\max a}=\frac{F_{\max }}{4 I} L . C
\end{aligned}
$$


with $E_{a}$ : the modulus of elasticity from the analytical approach, K: the stiffness, L: the span length, I: the cross-sectional area moment of inertia, $\sigma_{\max }$ : the maximal strength computed from the analytical approach, $\mathrm{F}_{\max }$ : the maximum load and c: the maximum distance to the neutral axis.

2/ using a numerical model and an inverse approach (Bosisio et al. 2007). In this case, the modulus of elasticity $\left(\mathrm{E}_{\mathrm{n}}\right)$ and the maximal strength $\left(\sigma_{\max n}\right)$ were identified using an inverse approach combining the finite element model of the rib and its corresponding experiment (load-displacement curve).

For each rib, custom software was used to build a rough mesh from masks representing the volume of interest of the cortical compartment exported as DICOM files Then the software Hypermesh (HyperWorks, Altair, USA) was used to refine the mesh with hexahedral elements. The external part of the model was defined as a shell with a thickness corresponding to the mean value of the cortical bone thickness derived from the HRpQCT. The internal part was composed of solid elements to represent the cancellous bone. Constitutive laws for both cortical and cancellous components of the model were elasto-plastic. Lower parts of the three-point bending device and the upper part were considered rigid cylinders. Simulations were then performed using LS-DYNA (LSTC, USA). A vertical loading was applied at $0.5 \mathrm{~m} . \mathrm{s}^{-1}$ in a manner similar to the experiments. Then the modulus of elasticity and the maximal strength of the cortical bone were adapted manually to fit the numerical load-displacement curve from the simulation with the curve from the corresponding experiment. A difference below $5 \%$ for stiffness and load was considered as obtaining the identified values $\left(\mathrm{E}_{\mathrm{n}}\right.$ and $\left.\sigma_{\max n}\right)$ from this inverse approach. The cancellous bone properties were kept constant for all specimens because they do not influence the rib response ( $\mathrm{Li}$ et al. 2010).

\subsection{Statistical analysis}

The descriptive statistics (mean and standard deviation) were calculated for each parameter. The Student test was used for paired comparisons and the Pearson coefficient was used to report the correlations between variables. The statistical analysis was performed using Statgraphics (version 16.2.03). 


\section{Results}

No statistical difference was found between rib levels 6 and 8 for either the ultrasonic or the mechanical properties from the numerical approach $(\mathrm{p}>0.10)$.

The nominal values for the velocity of the first arriving signal and the mechanical properties are presented for all the specimens in Table 1. The mechanical properties using both calculation methods are correlated, as seen in Table 2.

Statistically significant correlations were found between VFAS and both mechanical parameters (modulus of elasticity and maximal strength) (Table 2). The highest correlation coefficient was $0.78(\mathrm{p}<0.001)$ for the correlation between VFAS and the modulus of elasticity obtained from the inverse method (Figure 4).

\section{Discussion}

This study was designed to assess the relationship between quantitative ultrasound measurements (axial transmission) and mechanical properties of human ribs. No statistical difference was observed for the different parameters (ultrasonic and mechanical properties (numerical approach) on the $6^{\text {th }}$ and $8^{\text {th }}$ rib levels. Kemper et al. (Kemper et al. 2007) reported a similar observation for mechanical properties. To the best of our knowledge, ultrasonic velocities of human ribs measured using axial transmission have never been reported. Rib velocity (VFAS) values are typical of those found in long bones, such as the radius (Muller et al. 2008). Nevertheless, lower velocities $\left(3591 \pm 116 \mathrm{~m} . \mathrm{s}^{-1}\right)$ were measured on ribs in the current study compared to the velocity values reported for human radius specimens $\left(3946 \pm 93 \mathrm{~m} . \mathrm{s}^{-1}\right)$, which may be explained by the lower modulus of elasticity of the rib versus the radius (Bosisio et al. 2007). Mechanical properties are consistent with those Stitzel et al. (Stitzel et al. 2003) obtained when comparing anterior sample locations. Three-point bending overestimates the modulus of elasticity in comparison to coupon tension tests (Kemper et al. 2007). However, the modulus of elasticity is in the lower range of the previously reported data (Table 3). This result may be explained by the age of the subjects considered in the current work. As expected, the maximal strength was higher using the analytical approach than the numerical approach. The analytical approach is based on elastic beam theory and is known to overestimate the maximal strength (Burstein et al. 1972). 
No relationship between ultrasound measurement and the mechanical properties of the ribs has been reported previously. However, this type of relationship has been proposed on the radius (Muller et al. 2008). The modulus of elasticity was nicely predicted by the ultrasonic velocity of human ribs measured using axial transmission. The standard estimate of error (1.32 GPa) of the current study was determined in addition to the correlation coefficient, thereby validating the quality of the prediction.

Such results open the way for non-invasive assessment of input data for numerical models of the thorax for various ages in the population.

There are some limitations in the present study. First, the modulus of elasticity in the inverse approach is defined by a manual adjustment; an optimization routine would be more robust. The orientation of the rib in the High Resolution peripheral Quantitative Computed Tomography scanner was not strictly controlled. This may have affected the calculation of the cross-sectional area moment of inertia. The use of a tension coupon test instead of a three-point bending experiment would provide a more accurate measurement of the rib cortical bone material properties (Kemper et al. 2007). However, apparent properties (from 3-point bending) are related to ultrasound measurements, as shown in the current study. Finally, it would be worthwhile to assess the relationship between ultrasound measurements and failure strain given that the failure strain of cortical bone has been shown to decrease significantly with increased age (Lindahl et al. 1967; McCalden et al. 1993).

\section{Conclusions}

This study shows that for human ribs there is a significant relationship between the velocity of the first arriving signal (VFAS) assessed using ultrasound axial transmission and the mechanical properties obtained from bending experiments. This ex vivo study opens the way to the development of a methodology to non-invasively assess the material properties of ribs. This is a first step toward in vivo studies to obtain subject-specific rib properties.

\section{Acknowledgments}

The authors wish to acknowledge Georges Boivin and Hélène Follet for their important contribution in bones collection, Charlène Delimoge and Yuan Fang for their technical contributions to this study, and Nicolas 
Vilayphiou for his technical input regarding HR-pQCT data collection. This work was partly funded by the GDR 2610 “Biomécanique des chocs” (CNRS/INRETS/GIE PSA Renault).

\section{Conflict of interest statement}

There is no conflict of interest for any of the authors.

\section{References}

Agnew, A. M., Moorhouse, K., Kang, Y. S., Donnelly, B. R., Pfefferle, K., Manning, A. X., Litsky, A. S., Herriott, R., Abdel-Rasoul, M. and Bolte, J. H. t., 2013. The response of pediatric ribs to quasi-static loading: mechanical properties and microstructure. Ann Biomed Eng 41, 2501-2514.

Benameur, S., Mignotte, M., Destrempes, F. and De Guise, J. A., 2005. Three-dimensional biplanar reconstruction of scoliotic rib cage using the estimation of a mixture of probabilistic prior models. IEEE Trans Biomed Eng 52, 1713-1728.

Berteau, J. P., Pithioux, M., Follet, H., Guivier-Curien, C., Lasaygues, P. and Chabrand, P., 2012. Computed tomography, histological and ultrasonic measurements of adolescent scoliotic rib hump geometrical and material properties. J Biomech 45, 2467-2471.

Bosisio, M. R., Talmant, M., Skalli, W., Laugier, P. and Mitton, D., 2007. Apparent Young's modulus of human radius using inverse finite-element method. J Biomech 40, 2022-2028.

Bossy, E., Talmant, M., Defontaine, M., Patat, F. and Laugier, P., 2004. Bidirectional axial transmission can improve accuracy and precision of ultrasonic velocity measurement in cortical bone: a validation on test materials. IEEE Trans Ultrason Ferroelectr Freq Control 51, 71-79.

Bossy, E., Talmant, M., Peyrin, F., Akrout, L., Cloetens, P. and Laugier, P., 2004. An in vitro study of the ultrasonic axial transmission technique at the radius: 1-MHz velocity measurements are sensitive to both mineralization and intracortical porosity. J Bone Miner Res 19, 1548-1556.

Brumbelow, M. L. and Zuby, D. S. 2009. Impact and injury patterns in frontal crashes of vehicles with good ratings for frontal crash protection. In Proceedings of the 21st International Technical Conference on the Enhanced Safety of Vehicles. Washington, DC.

Burghardt, A. J., Buie, H. R., Laib, A., Majumdar, S. and Boyd, S. K., 2010. Reproducibility of direct quantitative measures of cortical bone microarchitecture of the distal radius and tibia by HR-pQCT. Bone 47, 519528.

Burstein, A. H., Currey, J. D., Frankel, V. H. and Reilly, D. T., 1972. The ultimate properties of bone tissue : the effects of yielding. J Biomech 5, 35-44.

Cormier, J. M., Stitzel, J. D., Duma, S. M. and Matsuoka, F., 2005. Regional variation in the structural response and geometrical properties of human ribs. Annu Proc Assoc Adv Automot Med 49, 153-170.

Crandall, J. R., Myers, B. S., Meaney, D. F. and Schidtke, S. Z. (2013). Pediatric Injury Biomechanics: Archive and Textbook. New York, Springer.

Dansereau, J. and Stokes, I. A., 1988. Measurements of the three-dimensional shape of the rib cage. J Biomech 21, 893-901.

Duchemin, L., Bousson, V., Raossanaly, C., Bergot, C., Laredo, J. D., Skalli, W. and Mitton, D., 2008. Prediction of mechanical properties of cortical bone by quantitative computed tomography. Med Eng Phys 30, 321328.

El-Jawahri, R. E., Laituri, T. R., Ruan, J. S., Rouhana, S. W. and Barbat, S. D., 2010. Development and validation of age-dependent FE human models of a mid-sized male thorax. Stapp Car Crash J 54, 407430.

Forman, J. L., Kent, R. W., Mroz, K., Pipkorn, B., Bostrom, O. and Segui-Gomez, M., 2012. Predicting rib fracture risk with whole-body finite element models: development and preliminary evaluation of a probabilistic analytical framework. Ann Adv Automot Med 56, 109-124.

Granik, G. and Stein, I., 1973. Human ribs: static testing as a promising medical application. J Biomech 6, $237-$ 240. 
Hildebrand, T., Laib, A., Muller, R., Dequeker, J. and Ruegsegger, P., 1999. Direct three-dimensional morphometric analysis of human cancellous bone: microstructural data from spine, femur, iliac crest, and calcaneus. J Bone Miner Res 14, 1167-1174.

Jiang, B., Cao, L., Mao, H., Wagner, C., Marek, S. and Yang, K. H., 2012. Development of a 10-year-old paediatric thorax finite element model validated against cardiopulmonary resuscitation data. Comput Methods Biomech Biomed Engin [Epub ahead of print].

Jolivet, E., Sandoz, B., Laporte, S., Mitton, D. and Skalli, W., 2010. Fast 3D reconstruction of the rib cage from biplanar radiographs. Med Biol Eng Comput 48, 821-828.

Kemper, A. R., McNally, C., Kennedy, E. A., Manoogian, S. J., Rath, A. L., Ng, T. P., Stitzel, J. D., Smith, E. P., Duma, S. M. and Matsuoka, F., 2005. Material properties of human rib cortical bone from dynamic tension coupon testing. Stapp Car Crash J 49, 199-230.

Kemper, A. R., McNally, C., Pullins, C. A., Freeman, L. J., Duma, S. M. and Rouhana, S. M., 2007. The biomechanics of human ribs: material and structural properties from dynamic tension and bending tests. Stapp Car Crash J 51, 235-273.

Kent, R., Henary, B. and Matsuoka, F., 2005. On the fatal crash experience of older drivers. Annu Proc Assoc Adv Automot Med 49, 371-391.

Kent, R., Lee, S.-H., Darvish, K., Wang, S., Poster, G. S., Lange, A. W., Brede, C., Lange, D. and Matsuoka, F., 2005. Structural and Material Changes in the Aging Thorax and Their Role in Crash Protection for Older Occupants. Stapp Car Crash J 49, 231-249.

Kilappa, V., Moilanen, P., Xu, L., Nicholson, P. H., Timonen, J. and Cheng, S., 2011. Low-frequency axial ultrasound velocity correlates with bone mineral density and cortical thickness in the radius and tibia in pre- and postmenopausal women. Osteoporos Int 22, 1103-1113.

Kimpara, H., Lee, J. B., Yang, K. H., King, A. I., Iwamoto, M., Watanabe, I. and Miki, K., 2005. Development of a Three-Dimensional Finite Element Chest Model for the 5(th) Percentile Female. Stapp Car Crash J 49, 251-269.

Kopperdahl, D. L., Morgan, E. F. and Keaveny, T. M., 2002. Quantitative computed tomography estimates of the mechanical properties of human vertebral trabecular bone. J Orthop Res 20, 801-805.

Li, Z., Kindig, M. W., Subit, D. and Kent, R. W., 2010. Influence of mesh density, cortical thickness and material properties on human rib fracture prediction. Med Eng Phys 32, 998-1008.

Lindahl, O. and Lindgren, A. G., 1967. Cortical bone in man. II. Variation in tensile strength with age and sex. Acta Orthop Scand 38, 141-147.

McCalden, R. W., McGeough, J. A., Barker, M. B. and Court-Brown, C. M., 1993. Age-related changes in the tensile properties of cortical bone. The relative importance of changes in porosity, mineralization, and microstructure. J Bone Joint Surg Am 75, 1193-1205.

Mitton, D., Zhao, K., Bertrand, S., Zhao, C., Laporte, S., Yang, C., An, K. N. and Skalli, W., 2008. 3D reconstruction of the ribs from lateral and frontal X-rays in comparison to $3 D$ CT-scan reconstruction. $J$ Biomech 41, 706-710.

Mizuno, K., Iwata, K., Deguchi, T., Ikami, T. and Kubota, M., 2005. Development of a three-year-old child FE model. Traffic Inj Prev 6, 361-371.

Muller, M., Mitton, D., Moilanen, P., Bousson, V., Talmant, M. and Laugier, P., 2008. Prediction of bone mechanical properties using QUS and pQCT: study of the human distal radius. Med Eng Phys 30, 761767.

Ruan, J., El-Jawahri, R., Chai, L., Barbat, S. and Prasad, P., 2003. Prediction and analysis of human thoracic impact responses and injuries in cadaver impacts using a full human body finite element model. Stapp Car Crash J 47, 299-321.

Song, E., Trosseille, X. and Baudrit, P., 2009. Evaluation of thoracic deflection as an injury criterion for side impact using a finite elements thorax model. Stapp Car Crash J 53, 155-191.

Stein, I. D. and Granik, G., 1976. Rib structure and bending strength: an autopsy study. Calcif Tissue Res 20, 61-73.

Stitzel, J. D., Cormier, J. M., Barretta, J. T., Kennedy, E. A., Smith, E. P., Rath, A. L., Duma, S. M. and Matsuoka, F., 2003. Defining regional variation in the material properties of human rib cortical bone and its effect on fracture prediction. Stapp Car Crash J 47, 243-265.

Subit, D., del Pozo de Dios, E., Velazquez-Ameijide, J., Arregui-Dalmases, C. and Crandall, J., 2013. Tensile material properties of human rib cortical bone under quasi-static and dynamic failure loading and influence of the bone microstucture on failure characteristics. arxiv.org/pdf/1108.0390.

Talmant, M., Kolta, S., Roux, C., Haguenauer, D., Vedel, I., Cassou, B., Bossy, E. and Laugier, P., 2009. In vivo performance evaluation of bi-directional ultrasonic axial transmission for cortical bone assessment. Ultrasound Med Biol 35, 912-919.

van Don, B., van Ratingen, M., Bermond, F., Masson, C., Vezin, P., Hynd, D., Owen, C., Martinez, L., Knack, S. and Schaeffer, R. 2003. Biofidelity impact response requirements for an advanced mid-sized male crash 
test dummy In Proceedings of the 18th Int. Technical Conference on the Enhanced Safety of Vehicles. Nagoya (Japan).

Vezin, P. and Berthet, F., 2009. Structural characterization of human rib cage behavior under dynamic loading. Stapp Car Crash J 53, 93-125.

Yoganandan, N. and Pintar, F. A., 1998. Biomechanics of human thoracic ribs. J Biomech Eng 120, 100-104.

Zhu, Y., Fang, Y., Bermond, F., Bruyere-Garnier, K., Ellouz, R., Rongieras, F. and Mitton, D., 2013. Relationship between human rib mechanical properties and cortical bone density measured by high-resolution quantitative computed tomography. Comput Methods Biomech Biomed Engin 16 Suppl 1, 191-192.

Zioupos, P. and Currey, J. D., 1998. Changes in the stiffness, strength, and toughness of human cortical bone with age. Bone 22, 57-66. 
Figure 1: The rectangle represents the location of the specimen $(120 \mathrm{~mm})$ cut from the rib.

Figure 2: Grey level image of a cross-section of a rib specimen performed by the HR-pQCT device (voxel size of $82 \mu \mathrm{m})$ illustrating bone tissue.

Figure 3: Three-point bending experiments. The rib specimens were placed on the lower supports (free to rotate) spaced by $100 \mathrm{~mm}$. The lower support and the impactor tip diameter were $10 \mathrm{~mm}$. The bending was oriented against the radius of curvature.

Figure 4: Relationship between modulus of elasticity (inverse method) of the ribs and the velocity of the first arriving signal, r=0.78, $\mathrm{p}<0.001$, Standard Estimate of Error (SEE)=1.32 GPa.

Table 1: Data on rib specimens (Ct.Th: Cortical Thickness, VFAS: Velocity of the First Arriving Signal, $E_{a}$, $\sigma_{\max a}, E_{n}$ and $\sigma_{\max n}:$ modulus of elasticity and maximal strength computed respectively from the analytical approach (subscript a) and from the numerical approach (subscript n)).

Table 2 : Correlation matrix between ultrasound velocity and mechanical properties (VFAS: Velocity of the First Arriving Signal, $E_{a}, \sigma_{\max a}, E_{n}$ and $\sigma_{\max n}$ : modulus of elasticity and maximal strength computed respectively from the analytical approach (subscript a) and from the numerical approach (subscript $n$ )).

Table 3: Comparison of the mechanical properties of the cortical bone from human ribs using tension coupon and three-point bending tests. 


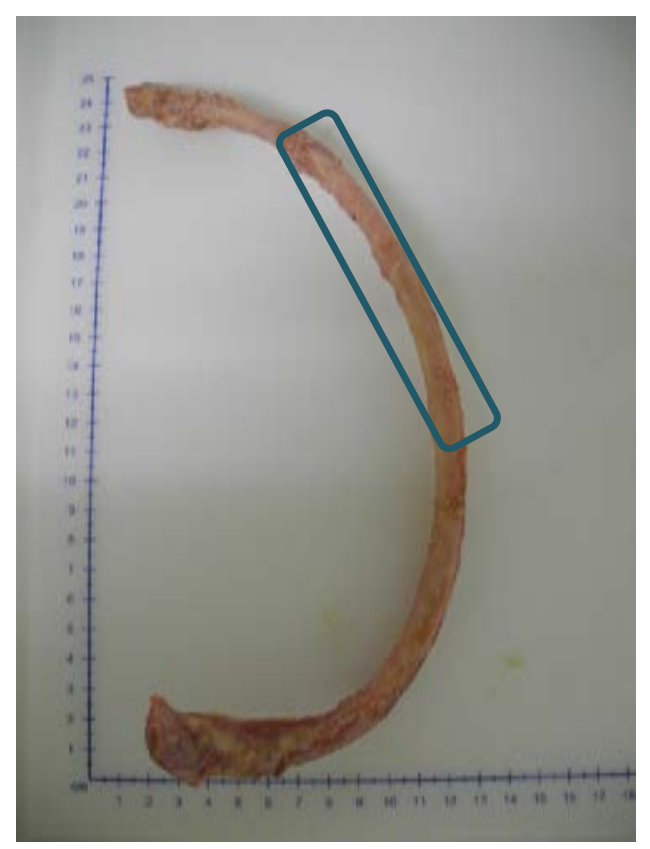

Figure 1 


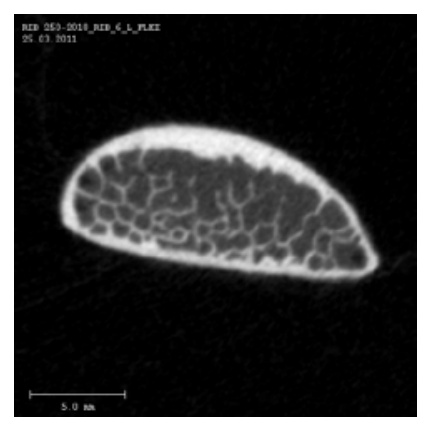

Figure 2 


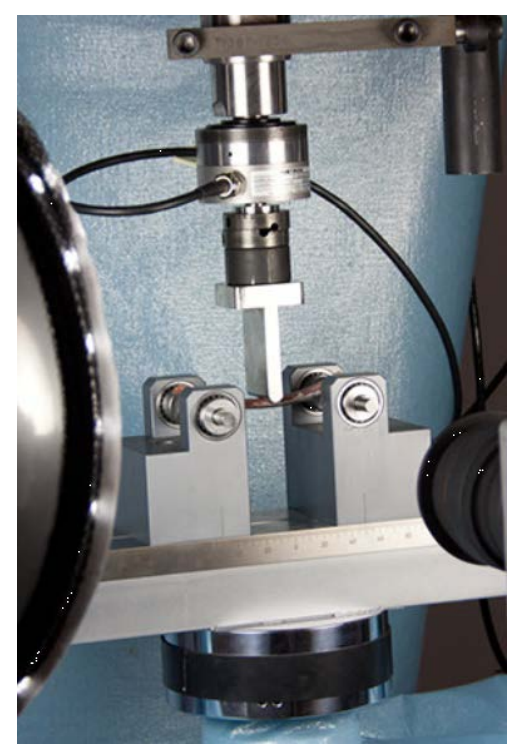

Figure 3 


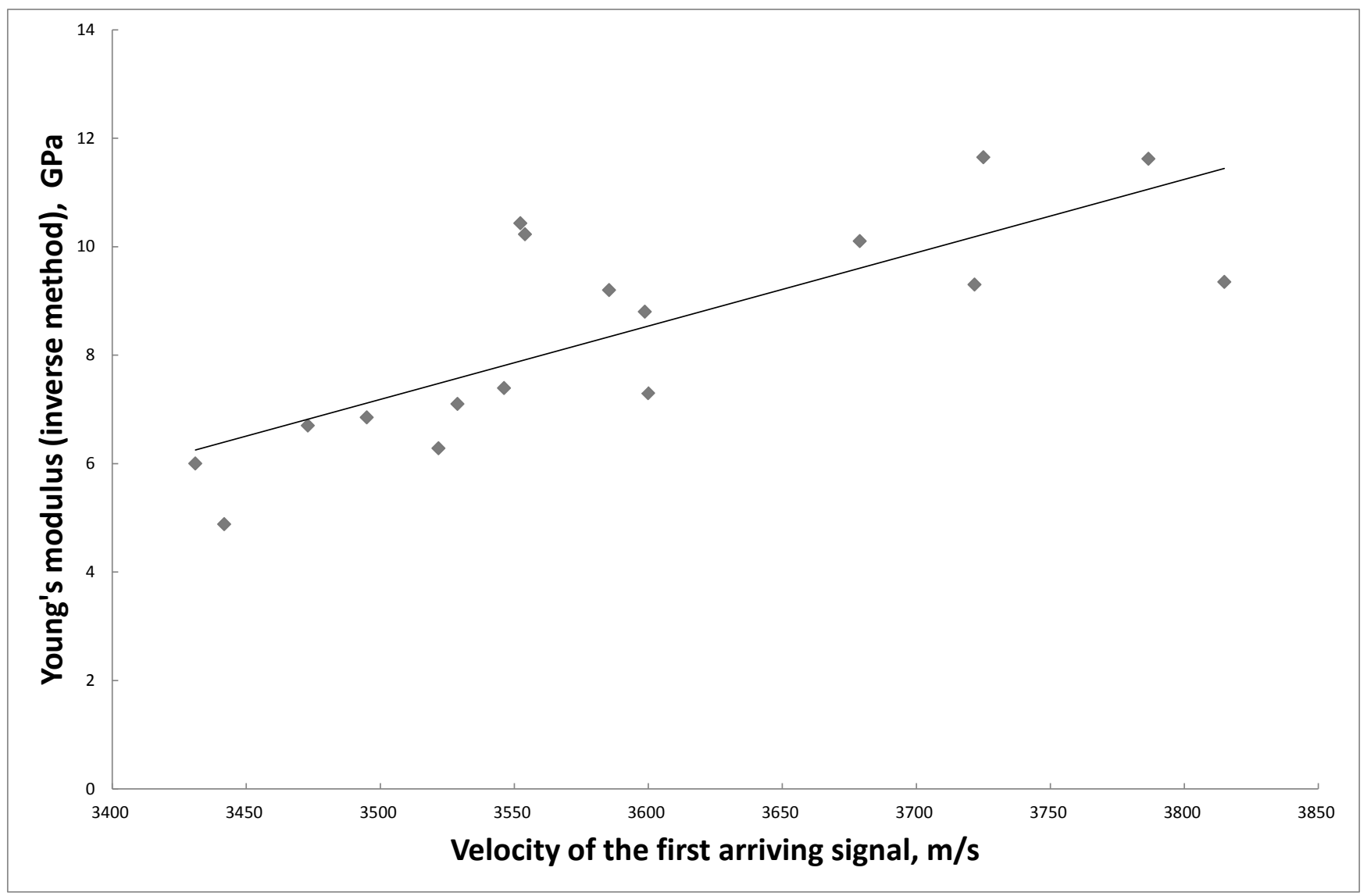

Figure 4 
Table 1

\begin{tabular}{|c|c|c|c|c|c|c|c|c|}
\hline Specimen & Age & Gender & $\begin{array}{l}\text { Ct.Th } \\
\text { (mm) }\end{array}$ & $\begin{array}{l}\text { VFAS } \\
(\mathrm{m} / \mathrm{s})\end{array}$ & $\begin{array}{c}E_{a} \\
(\mathrm{GPa})\end{array}$ & $\begin{array}{c}\sigma_{\max a} \\
(\mathrm{MPa})\end{array}$ & $\begin{array}{c}E_{n} \\
(\mathrm{GPa})\end{array}$ & $\begin{array}{r}\sigma_{\max n} \\
(\mathrm{MPa}) \\
\end{array}$ \\
\hline 1 & 85 & M & 0.69 & 3442 & 5.20 & 59 & 4.88 & 30 \\
\hline 2 & 67 & M & 0.83 & 3522 & 3.99 & 49 & 6.28 & 34 \\
\hline 3 & 80 & M & 0.94 & 3725 & 12.20 & 179 & 11.65 & 97 \\
\hline 4 & 80 & M & 0.93 & 3552 & 8.86 & 187 & 10.43 & 125 \\
\hline 5 & 65 & M & 0.72 & 3722 & 9.93 & 119 & 9.30 & 73 \\
\hline 6 & 85 & M & 0.87 & 3599 & 7.36 & 85 & 8.80 & 52 \\
\hline 7 & 67 & M & 0.95 & 3546 & 7.15 & 104 & 7.39 & 51 \\
\hline 8 & 80 & M & 0.91 & 3787 & 10.77 & 165 & 11.62 & 106 \\
\hline 9 & 80 & M & 0.93 & 3679 & 12.53 & 208 & 10.10 & 111 \\
\hline 10 & 77 & M & 0.75 & 3431 & 6.05 & 73 & 6.00 & 65 \\
\hline 11 & 77 & M & 0.79 & 3495 & 7.59 & 79 & 6.85 & 56 \\
\hline 12 & 82 & $\mathrm{~F}$ & 0.81 & 3473 & 6.90 & 71 & 6.70 & 58 \\
\hline 13 & 82 & $\mathrm{~F}$ & 0.82 & 3554 & 10.93 & 129 & 10.23 & 103 \\
\hline 14 & 89 & M & 0.91 & 3600 & 6.89 & 80 & 7.30 & 58 \\
\hline 15 & 89 & M & 0.87 & 3529 & 6.80 & 79 & 7.10 & 50 \\
\hline 16 & 50 & $\mathrm{~F}$ & 1.29 & 3815 & 9.48 & 219 & 9.35 & 115 \\
\hline 17 & 50 & $\mathrm{~F}$ & 1.05 & 3585 & 10.60 & 198 & 9.20 & 75 \\
\hline Mean & 75.6 & & 0.89 & 3591 & 8.43 & 123 & 8.42 & 74 \\
\hline deviation & 11.9 & & 0.14 & 116 & 2.47 & 58 & 2.03 & 30 \\
\hline
\end{tabular}


Table 2

\begin{tabular}{llllll}
\hline \multicolumn{1}{c}{$\mathrm{N}=17$} & $\mathrm{VFAS}$ & $\mathrm{E}_{\mathrm{a}}$ & $\sigma_{\max \mathrm{a}}$ & $\mathrm{E}_{\mathrm{n}}$ & $\sigma_{\operatorname{max~n}}$ \\
\hline VFAS & & $0,70^{*}$ & $0,72^{*}$ & $0,77^{* *}$ & $0,64^{*}$ \\
$\mathrm{E}_{\mathrm{a}}$ & $0,70^{*}$ & & $0,85^{* *}$ & $0,89^{* *}$ & $0,81^{* *}$ \\
$\sigma_{\max \mathrm{a}}$ & $0,72^{*}$ & $0,85^{* *}$ & & $0,81^{* *}$ & $0,88^{* *}$ \\
$\mathrm{E}_{\mathrm{n}}$ & $0,78^{* *}$ & $0,89^{* *}$ & $0,81^{* *}$ & & $0,85^{* *}$ \\
$\sigma_{\max \mathrm{n}}$ & $0,64^{*}$ & $0,81^{* *}$ & $0,88^{* *}$ & $0,85^{* *}$ & \\
\hline
\end{tabular}

${ }^{*} \mathrm{p}<0.01,{ }^{* *} \mathrm{p}<0.001$ 
Table 3

\begin{tabular}{|c|c|c|c|c|c|c|}
\hline Authors & $\begin{array}{l}\text { Nb subjects } \\
\text { (Age) }\end{array}$ & Rib level & Type of test & $\begin{array}{l}\text { Loading } \\
\text { speed } \\
(\mathrm{mm} / \mathrm{s})\end{array}$ & $\begin{array}{c}\text { Elasticity } \\
\text { modulus } \\
(\mathrm{GPa})\end{array}$ & $\begin{array}{l}\text { Failure strength } \\
\text { (MPa) }\end{array}$ \\
\hline $\begin{array}{l}\text { Kemper et } \\
\text { al. } 2005\end{array}$ & $\begin{array}{c}6 \\
(18-67)\end{array}$ & & TC & & 13.9 & 124.2 \\
\hline $\begin{array}{l}\text { Kemper et } \\
\text { al. } 2007\end{array}$ & $\begin{array}{c}6 \\
(42-81) \\
\end{array}$ & & TC & & 14.4 & 130.9 \\
\hline $\begin{array}{l}\text { Subit et al. } \\
2013\end{array}$ & $\begin{array}{c}3 \\
(54,67,71)\end{array}$ & 6 and 7 & TC & $\begin{array}{c}0.01 \text { and } \\
0.02\end{array}$ & $13.5(2.6)$ & $112.1(24.5)$ \\
\hline $\begin{array}{l}\text { Sitzel et al. } \\
\text { (2003) }\end{array}$ & 4 & & $\begin{array}{l}\text { 3PB on } \\
\text { rectangular } \\
\text { rib cortical } \\
\text { bone } \\
\text { specimens }\end{array}$ & & $\begin{array}{c}\text { Anterior } 7.5 \\
\text { Lateral } \\
11.8\end{array}$ & $\begin{array}{c}\text { Anterior 116. } 7 \\
\text { Lateral } 153.5\end{array}$ \\
\hline $\begin{array}{l}\text { Yoganadan } \\
\text { et al. } 1998\end{array}$ & $\begin{array}{c}30 \\
(29-81) \\
\text { Mean : 63.6 }\end{array}$ & 7 and 8 & $\begin{array}{l}\text { 3PB on rib } \\
\text { sections }\end{array}$ & 0.04 & $\begin{array}{c}\text { Rib 7 } \\
2.32(0.36) \\
\text { Rib 8 } \\
1.89(0.29)\end{array}$ & \\
\hline $\begin{array}{l}\text { Kemper et } \\
\text { al. } 2007\end{array}$ & $\begin{array}{c}6 \\
(42-81) \\
\end{array}$ & $4-9$ & $\begin{array}{l}\text { 3PB on rib } \\
\text { sections }\end{array}$ & 172 & $\begin{array}{c}\text { Anterior } 18.9 \\
\text { Lateral } 21.1\end{array}$ & \\
\hline $\begin{array}{c}\text { Current } \\
\text { study }\end{array}$ & $\begin{array}{c}9 \\
(67-80)\end{array}$ & 6 and 8 & $\begin{array}{l}\text { 3PB on rib } \\
\text { sections }\end{array}$ & 500 & $\begin{array}{c}\text { Analytic } \\
8.43(2.47) \\
\text { Inverse } \\
\text { method } \\
8.24(2.03)\end{array}$ & $\begin{array}{c}\text { Analytic } \\
123(58) \\
\text { Inverse method } \\
74(30)\end{array}$ \\
\hline
\end{tabular}

TC: Tension coupon, 3PB: Three-point bending 